\title{
How are you hoping to die?
}

\section{John Launer}

If you ask people how they hope to die, you will usually hear two kinds of answers. Some people want to go very quickly, for example, through a sudden massive stroke, preferably in their sleep. Others would rather have a couple of years to come to terms with the prospect of death: a gradual decline from cancer, perhaps, with time to fulfil their last cherished wishes, put their affairs in order and gather their family around them for the end. I would have given the second of these answers myself in the past, mainly because both my parents died suddenly (my father from a heart attack; my mother from a pulmonary embolus). It seemed very cruel for their lives to be cut-off so abruptly, with so much undone and unsaid. Now, I am no longer sure about my answer. I have seen other relatives and friends decline in slow and miserable ways that seemed worse than dying suddenly. I also experienced a cardiac arrhythmia a couple of years ago, when a black curtain came down in an instant, rendering me unconscious in presumably the same way as it does in quick deaths. It was not pleasant, but nor was it particularly unpleasant. Apart from knowing the distress it would cause to people close to me, this manner of death is the one I would possibly opt for now, if given the choice-although a pacemaker has significantly reduced the chances of this happening.

In reality, of course, there is no choice in such matters. We die in a wide range of ways and, to be blunt, no-one would put most of these on their wish list. Deaths involving long-term loss of function, like motor neuron disease or dementia, are universally feared. Road accidents, although sudden, are horribly brutal. Even suicide can fail or be gruesomely prolonged. Cancer may sometimes proceed from diagnosis to death within weeks or even days, with no time to start treatment, or even to arrange good terminal care. Probably the majority of deaths, at least in developed countries, occur after a few days of acute illness but against a background of longer decline or advanced age. These deaths still usually come as a shock. Individuals may have survived years of frailty, many courses of chemotherapy or previous

Correspondence to Dr John Launer, Postgraduate Medical Journal, London WC1H 9JP, UK; johnlauner@aol.com chest infections, and have no particular reason to fear that the next one might be fatal. Often, no one has taken the trouble to warn the patient or the family that death may arrive in this rapid and unpredictable way-during a short unplanned admission surrounded by unfamiliar attendants. Such very common scenarios of dying are the ones that health services seem most poorly equipped to deal with, and are among the most upsetting. ${ }^{1}$

\section{DISCUSSING DEATH}

The taboo on discussing deathappears to be lessening. 'Death cafés' have arrived in the USA and western Europe so that anyone can find a place to talk about their hopes and fears of what will happen when their time arrives. ${ }^{2}$ Articles and books about dying seem to be coming out every month. Much recent writing about the subject concerns the issues of medicalisation, overdiagnosis and overtreatment, and how we avoid accepting the fact that life is 'actually brief and universally precarious.' 3 Atul Gawande's book on these topics, 'Being Mortal', has become a bestseller. ${ }^{4}$ Another book, called 'Life, Death and the Illusion of Control', by the science writer Barbara Ehrenreich, is a polemic against living too long. ${ }^{5}$ Drawing on her own personal experience as a patient, and offering a passionate critique of the cultural trends that discourage us from accepting death, she counsels everyone over 70 to express a clear wish to refuse any investigation or treatment that will do anything other than make their lives comfortable. (Unfortunately, her zeal leads her to discount other possible choices, and to tarnish some good preventive and curative treatments as well.)

Taking a gentler approach, palliative care specialist Kathryn Mannix has written a book to reassure everyone that it is possible for death to be gentle and untroubled, especially if it occurs in a hospice. ${ }^{6}$ She suggests we should describe to dying people and their families exactly what the stages of their demise will look like, in order to reduce their fears. Her book is particularly strong on explaining how to listen and respond to the dying, and to talk with them about the most difficult subjects. She describes how her working life is illuminated by seeing people whose deaths have seemed like watching a rose unfurl to perfection.' She supports her case with moving tales from her own practice-leaving one feeling how lucky her own patients must be, but also perhaps with heightened concerns about the harrowing deaths that take place in less ideal circumstances.

Such concerns are addressed head on in a book called 'The Way We Die Now', by the Irish physician Seamus O'Mahony. ${ }^{7}$ As a specialist in alcoholic liver disease, he has sometimes seen the very worst of deaths-from exsanguination as a result of oesophageal varices, including in young people. It has made him unromantic about death, with little patience for those who want to rebrand dying as 'almost a form of personal growth.' He laments the loss of proximity to death that made it seem far more familiar and natural to previous generations. $\mathrm{He}$ lampoons the glossy caricature of the 'good death' that appears in policy documents, and that the public have been deceived into regarding as universal. $\mathrm{He}$ cautions us to anticipate that our terminal care may be more of a piece with the rest of modern medicine. With evident relish, he quotes the Italian doctor Domenighetti, who believes this is characterised by 'complexity, uncertainty, opacity, poor measurement, variability in decision-making, asymmetry of information, conflict of interest and corruption.'

\section{OUR OWN ENDINGS}

These different approaches each make sense, but I have reservationsabout how helpful they are in preparing for our demise. As O’Mahony reminds us, even philosophy provides no guarantee about our own endings, happy or otherwise. Montaigne, who spent all his adult life contemplating his mortality and writing about it with grace and equanimity, choked to death grotesquely on his quinsy. Ludwig Wittgenstein, apparently the most troubled of philosophical souls, died peacefully under the loving care of his own general practitioner (GP) Edward Bevan and his wife Joan, who had taken him into their home in Cambridge in his dying weeks. (Bevan was my own GP as a student, 20 years later. I found him rather austere and had no idea of this extraordinary act of kindness.)

Perhaps it is now time for doctors to think more about the manner of everyone's death, rather than focusing so much on the causes. We still have too little knowledge of the different kinds of trajectory towards death, and the likelihood of each. All these recent books-whether 


\section{On reflection}

in the form of caustic warnings or comforting reassurance-are largely based on personal impressions. As a profession, we lack an epidemiology of dying, both quantitative and descriptive, to inform us. We urgently need this, so that we cantalk more openly with patients about the range of modes of dying, our inability to predict which of these most individuals will face, and the limits on our capacity to bring everyone to a 'good death.' As mortal beings ourselves, we might also prefer to plan in advance for all the possible eventualities with less self-deception and evasion, and to preparenot just for the death that we might be hoping for, but for endings of every kind.

Funding The author has not declared a specific grant for this research from any funding agency in the public, commercial or not-for-profit sectors.

Competing interests None declared.

Patient consent Not required.

Provenance and peer review Not commissioned; internally peer reviewed.

(c) Author(s) (or their employer(s)) 2019. No commercial re-use. See rights and permissions. Published by BMJ.

\section{(D) Check for updates}

To cite Launer J. Postgrad Med J 2018;94:671-672.
Published Online First 15 December 2018

Postgrad Med J 2018;94:671-672.

doi:10.1136/postgradmedj-2018-136260

\section{REFERENCES}

1 Launer J. Reinventing palliative care. Postgrad Med J 2016;92:427-8.

2 Death Cafe. 2018. Available: https://deathcafe.com [Accessed 22 Sep 2018].

3 Guglani S. Death. The Lancet 2018;392:205.

4 Gawande A. Being mortal: illness, medicine and what matters in the end. London: Profile Books, 2015.

5 Ehrenreich B. Natural causes: life, death and the illusion of control. London: Granta, 2018.

6 Mannix K. With the end in mind: dying, death and wisdom in an age of denial. London: Collins, 2017.

7 O'Mahony S. The way we die now. London: Head of Zeus, 2016. 